\title{
5. Spiritual Localization and De-localization: Traditional and Modern Patterns in Hindu Pilgrimage
}

Heinz Werner Wessler

\section{Abstract}

Going on pilgrimage is a vivid tradition in India and its masterpiece, the Kumbh Mela, is probably the biggest mega-event of its kind in the world. The identification of holy places at established places of pilgrimage is an ongoing process even in our times, contributing to the diffusion-mechanisms of certain pilgrimages. In contradiction to this, the criticism of the institution of pilgrimage has formed an important stream for centuries. The monistic tradition in Hinduism has produced many popular poems that question the reward of religious journeying and ritual bathing at holy places, or that transform pilgrimage into a metaphor for inner journeys towards liberation.

\section{Introduction}

Numerous places all over on the map of South Asia attract millions of Hindu pilgrims every year. Some of them draw predominantly regional pilgrims, ${ }^{240}$ others draw pilgrims from all over India. Some traditional places are on the decline, others are gaining in

${ }^{240}$ Compare for example the many pilgrimage-sites in the Central Himalayas in Datar I961 and Berreman I963.

How to cite this book chapter:

Wessler, H. W. 202I. Spiritual Localization and De-localization: Traditional and Modern Patterns in Hindu Pilgrimage. In: Larsson, S. and af Edholm, K. (eds.) Songs on the Road: Wandering Religious Poets in India, Tibet, and Japan. Pp. 93-I I2. Stockholm: Stockholm University Press. DOI: https://doi .org/Io.I6993/bbi.e. License: CC-BY 4.0. 
importance, like the pilgrimage to Amarnath in Kaśmīr, which together with its religious meaning also has a political meaning, since it marks Kaśmīr as a part of the holistic setup of Indian national territory. ${ }^{24 \mathrm{I}}$ The ranking is flexible, and new places come up, often together with upcoming school-traditions that draft their own religious landscape and mark sacred places, as for example the pilgrimage to the temples of the Swāmīnārāyaṇs or to the Sai Baba of Sirdī that go back to charismatic founders or new formations in the $19^{\text {th }}$ and early $20^{\text {th }}$ century. Large-scale road construction work is going on at many places, as for example along the upper Gangā to the pilgrimage places in the Central Himālayas. Bhadrināth, Gañgotrī, and other places that are high up in the mountains, are more and more easily accessible by car and bus, and even by helicopter. ${ }^{242}$ Walking pilgrims, expecting a better reward for the trouble, are still visible, but modern transportation has radically changed the nature of pilgrimage overall. Easy accessibility has become important for the great majority of religious travellers.

Religious pilgrimage (tīrthayātrā), and particularly Hindu pilgrimage, is blossoming in contemporary India probably like never before. Many traditional texts like the epics and the Purānas have long sections on rewards for certain pilgrimages (phalastuti). The phalastuti very often forms an integral part of religious narrative texts, particularly those directly or indirectly related to certain places of pilgrimage (sthalapurānas). ${ }^{243}$ These texts are mostly in the classical holy language of Hinduism, that is Sanskrit, sometimes transmitted as independent texts, but are often included in larger canonical works, mostly epics and Purānas. The phalastuti often refers explicitly to the trias of yātrā (travel), darśana (seeing the divine image/symbol), and snāna (purification in water) that define the common essential of pilgrimage. ${ }^{244}$ They are often accompanied by other activities like mundana (ritual head-shaving),

${ }^{24 \mathrm{I}}$ www.jammu.com/shri-amarnath-yatra/schedule.php (I9.I.20I9)

${ }^{242}$ A regular helicopter service is offered for one day pilgrimages from Dehradun to Bhadrināth, compare: chardhampackage.com/badrinath-yatra -by-helicopter.html (I9.I.2019)

${ }^{243}$ Compare Bhardwaj I973:1 53, 216-224 for a case study of text sources on Haridwar. Compare also the nine case studies in Bakker I990.

${ }^{244}$ Bhardwaj I973: 53. 
pindadāna (sacrifice of rice-balls to the ancestors), investiture of the holy thread, and other rituals.

Singh, who has published on Banaras as a centre of Hindu pilgrimage for decades, describes the overall function of pilgrimage as "deeper interconnectedness", ${ }^{245}$ and the landscape of the place of pilgrimage as "sacredscape". These trendy abstractions may be attractive for Western observers or eventually researchers, but they are - in English original or some kind of translation into Indian languages - quite far away from the reference-frames of the great majority of the pilgrims. In any case, the circulation-mechanism through pilgrimage has certainly contributed a lot to the identity of Hinduism as a conclusive whole ${ }^{246}$ and it still fulfils this function in contemporary India.

Besides, while in colonial India, and even in the decades after independence, pilgrimage was largely perceived as a kind of inferior form of performing Hinduism, it has somehow entered the centre-stage in the meantime. The recent holy dip at the central place of the 2019 Kumbh Mela in Prayagraj (Allahabad) of the chief minister of the state of Uttar Pradesh, Yogi Adityanath (BJP), together with a group of members of his cabinet, was covered by the media all over India. ${ }^{247}$ Following this media event, oppositional Congress Party leaders, including Priyanka and Rahul Gandhi, also started to decide going for the holy dip. ${ }^{248}$ This recent development demonstrates how pilgrimage has political dimensions and political functions, particularly in contemporary discourses on identity-politics in India.

At the same time, traditional as well as modern Hinduism has produced manifest forms of criticism of the institution of pilgrimage and religious journeying as such and can even be explicitly polemical. Besides, textual sources for pilgrimages have sometimes a metaphorical meaning and are not necessarily meant

${ }_{245}$ Compare Feldhaus 2003.

${ }_{246}$ Glasenapp I928; Bhardwaj I985; Feldhaus 2003.

${ }_{247}$ Compare: www.indiatoday.in/india/story/yogi-adityanath-does-a-har -har-gange-takes-dip-during-kumbh-mela-at-prayagraj-I 44 I 808-20 I 9 -OI-29 (30.1.2019)

${ }^{248}$ www.indiatoday.in/india/story/priyanka-gandhi-may-begin-political -innings-with-holy-dip-at-kumbh-I439977-20I9-0I-26 (I.2.20I9) 
literally. For example, a Yogi can perform a pilgrimage to the seven shrines in meditation, without any physical move. ${ }^{249}$

\section{The pilgrim and the tourist}

A Google-search after places of pilgrimage in India quickly reveals a certain canon of places - mostly Hindu, but some Muslim or possibly other religions. Most of these websites are designed for the growing market of tourists who would like to observe and to a certain degree participate in religious life that is not the religious life of their own. ${ }^{250}$ Titles like "Best pilgrimage and religious sites in India" ${ }^{251}$ clearly appeal to the grey zone between observation and participation. While "Visit Dargah Sharif" points more to the tourist as observer - perhaps not by chance a Muslim pilgrimagecentre - "Take a boat ride" in the artificial lake in the recently constructed gigantic Akshardham temple-compound in Delhi goes a step further from tourism to pilgrimage. "Engage in a trek to the Amarnath Caves" maintains the ambiguity between trekking and pilgrimage that seems to be part of the marketing strategy, while "Take part in the Holla Mohalla" (Sikh festival) and "Take a holy dip" point to performative, participatory activities.

"Tour packages" that include a certain, though limited, participation in religious festivals are common. Some sites operate freely with self-affirmative statements like "In India we find oldest pilgrimage tradition in the whole world" ${ }^{52}$, "You can find numerous temple towns, exotic pilgrimage sites and unique rituals in the country" ${ }^{253}$, or commonplaces like "India is a land of spirituality" 254 . They invite to book "spiritual tour packages" focused on the visit of old and modern centres of pilgrimages, et cetera. The great majority of these websites focus on international tourists. The emphasis on experience in touristic discourse aligns tourism

\footnotetext{
249 Bharati I 963.

250 Jacobsen 2009:407f.

${ }^{251}$ www.indianholiday.com/best-of-india/pilgrimage-religious (I9.I.20I9)

${ }_{252}$ Compare: www.culturalindia.net/indian-pilgrimage (I9.I.20I9)

253 www.travelogyindia.com/pilgrimage-tours (I9.I.20I9)

254 www.hindustantimes.com/india-news/a-record-over-24-crore-people -visited-kumbh-20 I 9-more-than-total-tourists-in-up-in-20 I 4-I 7/story -9uncpmhBPnBji I ClnTiYQP.html (6.I0.2020)
} 
with religion in the modern world in general and with the focus on religious experience in modern Hinduism in particular. ${ }^{255}$

The discovery of traditional places of pilgrimage by the tourism-industry is part of the dynamics of contemporary tourism. Naturally, it leaves hardly any space for the complicated debates on religious merits of religious travelling to certain places or of pilgrimage in general, on how meaning is created, reinforced, and maintained through pilgrimage. It supports a view that religious identities are substantial, fixed, and unchanging. Tourism is sympathetic and affirmative to pilgrimage. It questions the identity of the pilgrim more implicit than explicit by exposing her or him to the observant view from outside that the tourist persistently maintains even if she or he participates to a certain extent.

Besides, the Hindu pilgrim and the national or international tourist have much in common. They both take photographs of themselves together with landmarks of the pilgrimage-place, sometimes in devotional postures. They both are interested in purchasing souvenirs and gifts, and they avail themselves of the same transportation and sometimes lodging accommodations. Tourists visiting Hindu temples and pilgrimage-sites often participate in religious rites, sometimes under the pressure of templepriests (in expectation of a certain amount of money as reward for their services), out of curiosity or eventually because they are overtaken by religious sensations and a sense of participation in religious rituals. Religious pilgrims are often interested in visiting non-religious places while on pilgrimage. ${ }^{256}$ In other words, the binary of "outer journey" and "inner journey", which is also part of the traditional criticism of pilgrimage within the Hindu tradition, is always blurred. ${ }^{257}$ Overall, tourism to pilgrimage-places and festivals related to pilgrimages do not appear to have a destabilizing effect on the tradition of Hindu pilgrimage, but rather complement its attraction and affirm it.

The biggest, and most spectacular, religious pilgrimage of India and the world, is the Kumbh Mela. It takes place every three years at four different places (Allahabad, Haridwar, Ujjain, and Nasik)

\footnotetext{
255 Compare Bremer 2005; Singh 2006.

${ }^{256}$ Bremer 2005.

257 Singh 2006 strongly emphasizes touring and pilgrimage as a binary.
} 
and the festival at the confluence of the rivers Gangā and Yamunā - plus the mythical Sarasvatī - is the most important place of the Kumbh Mela. The confluence of the three rivers (triven $\bar{\imath})$ is perceived as a holy site and place of pilgrimage any time, but the Kumbh Mela is believed to be the most auspicious time to visit it. Pilgrims come from across India in millions: simple farmers and their families, businessmen, whole villages, and the picturesque "holy men", sādhus from all over India. The recent Ardh Kumbh Mela in Prajagraj (Allahabad) had to deal with an incredible number of nearly 250 million visitors according to news reports. In other words, an extreme form of mass mobilization within the rather narrow time-frame of only a few weeks, between Makar Sankranti on January $15^{\text {th }}$ and Shivratri on March $4^{\text {th }}$ 2019. Among the visitors were supposedly more than one million foreign nationals, mostly tourists in the strict sense of the term. Tents were set up in an area of about 24 square kilometres at the holy site, an incredible number of I 22000 mobile toilets and drainage systems, dozens of pontoon bridges over the rivers, I 50 kilometres of newly constructed roads, electricity-grids, hundreds of new bus stations and even several provisional hospitals. Beyond the central planning, more than 5000 more or less self-organized mobile ásrams were set up by the many Hindu religious orders that participated, many of them rivalling and sometime fighting over the best places closest to where the rivers actually meet.

The logistics of a Kumbh Mela is incredible. Rahul Mehrotra calls the town of tents a "pop-up megacity" and regards it as a case of "extreme urbanism". Mehrotra is editor of a book based on the research work of a project based at Harvard University to study the Kumbh Mela as exceptional temporary urban planning. ${ }^{28}$ Tens of thousands of police officers and a range of government institutions collaborate to create a transient urban space and ensure the working of the makeshift structure for millions of pilgrims. Particular care has to be taken that there are no stampedes, which in the past have led to many casualties. Fortunately, no serious stampede has happened in recent decades through the ever-growing history of the Kumbh Mela. Epidemics or other

${ }^{258}$ Mehrotra 201 5: Introduction. 
public health-disasters also have to be prevented as millions of pilgrims pass through. The mega-event is accompanied by thousands of journalists and photographers, including a great number of foreign nationals in their search for extraordinary images. The official website includes information in English and Hindi for pilgrims as well as tourists; it also offers the standard "tourpackages", including overnight stays, guide, and a secure place for the holy dip at one of the more prominent places. Tourists and pilgrims are offered to "meet the mystics and witness their miracles", to "experience the power of spirituality", and similar references to orientalist clichés that have entered the mainstream imagining of India. ${ }^{259}$

\section{Braj - spiritual and geographical}

Besides the classical places of pilgrimage in mainstream Hinduism that go back to the first millennium CE, there are a lot of sacred places that were "identified" as such much later. This is particularly true for the holy places - i.e. pilgrimage-sites - related to Kṛ̣na. The $I 6^{\text {th }}$ century proved to be a crucial epoch for the identification of places where Kṛșna used to "play", according to the canonical account in the Bhāgavata-Purāna. The village where Kṛ̣na grew up, Braj, was lost until then. The then recently founded schooltraditions puștimārg (founded by Vallabhācārya, circa I479-I 53 I) and gauḍ̂ya vaișnava sampradāya (founded by Caitanya, circa I $485^{-I} 533$ ) were particularly active in this process of identification of the geographical places of Kṛṣna's plays. This development responded to the blossoming of devotional Krishnaism (krṣnabhakti) during the epoch mentioned. Braj was "lost and found" ${ }^{260}$, and Vallabhācārya personally came to the region to identify particularly the hill Govardhan, which Kṛṣna had lifted in order to provide a sheltered space for the village people, when Indra had sent a heavy storm. Govardhan immediately became an important pilgrimage-centre of the puștimārg. Caitanya sent his two important pupils Sanātan och Rūp Goswāmī to Braj, who "saved" a great many "places of play" (līlāsthal) within the

\footnotetext{
259 www.kumbh.gov.in/en (I9.1.2019)

260 Vaudeville I976.
} 
fifteen years of their stay. Caitanya himself discovered several places through divination, when he personally came to village Vrnndāvan in I 5 I 5 CE. ${ }^{261}$ The traditional biography of Caitanya (Caitanyacaritāmrta) in chapter 20 of the madbyalīlā-part reports an episode during the stay of Caitanya in Vrndāvan, when he asked the people of the village where the Rādhākund pond was, where Kṛ̣ṇa and Rādhā used to "play" in the water (jalakrị̣̂a). Nobody knew. Hearing this, Caitanya started to search the village for hints, and he finally found a small pond, which he could positively confirm as the place of the jalakrī $\bar{a}$, whereupon Caitanya and his followers, overwhelmed by the joy of having found the real place, started to sing and dance to the glory of Krṣna. ${ }^{262}$

It is said that some Kadamba trees in the region still bear fresh marks of Kṛṣna leaning against them with his crown (mukuț). In other words, Kṛ̣na’s "play" is somehow ongoing, and the divine Vṛndāvan, where Kṛṣna dances with the Gopīs (rāslīlā) eternally, somehow continually leaves its imprint on the mundane Vrndāvan. Theologically speaking, the "play" never ended, and the interaction between the two Vṛndāvans - divine and mundane, eternal and historical - continues. It is ongoing, even though not always clearly visible. ${ }^{263}$ The mundane Braj mandal - the region around Mathurā in Western Uttar Pradesh - is a world parallel to the eternal Braj that is not bound to time and place.

In our present dark age, the kaliyuga according to Hindu belief, mundane Braj with all the identified places of Krṣna's appearance, with all its temples and bathing-places along the Yamunā river, is but a shadow of the timeless Braj. The decline is clearly visible in Govardhan, which is no longer a hill, as it used to be in the time of Kṛ̣na's pastimes, but almost flat as the rest of the landscape. Kṛ̣na is present and absent at the same time during the modern pilgrimage. The pilgrim suffers with the Gopiss after Kṛ̣na's leave to Mathura from his absence. Kṛṣna has left his marks in the region, he is somehow present, but antardhāna, i.e. he disappeared. Any visitor can observe how strong the emotional effect of this iden-

\footnotetext{
26. Compare Vaudeville I976; Entwistle I987.

${ }^{262}$ Compare: www.radhanathswamiweekly.com/radhanath-swami-glories -sri-radha-kunda (I9.1.2019)

263 Vaudeville I976; Entwistle I987.
} 
tification with the Gopiss can be. A strange mixture of intense joy and desperation sometimes visibly overwhelms pilgrims.

The popular versions of the Bhägavata-Purāna in Braj or Modern Standard Hindi - as for example the much read Premsāgar ("Ocean of Love") of Lallūlāl - go much into the details of the exalted behaviour of the Gopis after Kṛnna had left them for themselves. They perform Kṛnna's "plays”, they recall what he did and what he said, they cry, consulate each other, become obsessed in panic, and faint. Gopībhàv, the sentiment of the Gopis, is the highest form of spiritual consciousness in Krishnaism. Some groups, like the Haridāsīs, go as far as to enact this mystical transsexualism in practical terms: Haridāsī men may wear female clothes in Braj. The "gender of longing" is female. ${ }^{264}$ The poetry that goes under the name of the Rajput princess Mīrābāî (I498-I 547), who renounced her status in order to be Kṛṣna’s beloved, may give a vivid example of this kind of emotion:

With my tears,

I watered the creeper of love that I planted;

now the creeper has grown spread all over,

and borne the fruit of bliss.

The churner of the milk churned with great love.

When I took out the butter, no need to drink any buttermilk.

I came for the sake of love-devotion;

seeing the world, I wept. ${ }^{265}$

Mīrābāī saw herself as married to a statue of the Giridhar Nāgar, i.e. Kṛṣna who holds the Govardhan-mountain above himself to protect the inhabitants of Vṛndāvan from storm. In another poem that forms part of the Sikh Guru Granth Sāhib, Mīrābāì is quite explicit on the pain she is suffering because of Kṛṣna's absence:

Arrows like spears: this body is pierced and, Mother, he's gone far away.

When did it happen, Mother? I don't know

but now it's too much to bear. ${ }^{266}$

\footnotetext{
${ }^{264}$ Hawley 2005:I67 on Mīrābāī.

${ }^{265}$ Mīrābāī I980, translation by Anthony Alston.

266 Translation by Hawley 2005:I68.
} 
The hymn is a dialog between a Gopī and her mother, pointing to the lover that abandoned her, but on a spiritual level it is about the experiences of the believer with the absent God. In I $6^{\text {th }}$ century Krishnaism, Kṛṣna's absence ranges among the most prominent subjects. Even though viyoga (separation) dominates over samyoga (being together), the Gopīs are continuously convinced that their emotional form of bhakti (devotion) is more substantial than the more abstract advaita vedānta. This becomes particularly clear in the dialog with Kṛṣna's messenger Uddhava in Braj, given in Bhāgavata-Purāna I0.48. Uddhava tries to convince the Gopīs that a more detached, non-dualist spirituality is somewhat better than the emotional and even ecstatic religious performance they practice. Uddhava, however, leaves Vṛndāvan defeated. He understands that the saguna ('qualified', i.e. personal) form of bhakti, with the person of Krṣna as its centre, is the highest form of bhakti. The Gopīs' performative memorization of Krșna's "play" $(\operatorname{li} l \bar{a})$ is a form of bhakti more advanced than what he knew until then. God is not all-over in the sense that he is invisible and formless. He manifests himself in time and space as a pūrṇāvatāra ('full manifestation'). In brief, monotheism is more advanced than monism.

\section{Traditional and contemporary pilgrimage}

The pilgrimage to mundane Braj plays an important role for Krishnaites from the $16^{\text {th }}$ century onwards, when the canonical list of holy places was basically laid out. The sacred landscape is constantly enlarged and revised until today. ${ }^{267}$ One of the more recent innovation for example is the "temple of the foreigners" (angrezom kā mandir), as the Sri Sri Krishna Balaram Mandir ${ }^{268}$ (ISKCON or Hare Krishna Temple) is conveniently called in Hindi. The construction of the I970s was not particularly welcomed in Vṛndāvan, especially after rumors about drug-trafficking and a murder-case on the temple-compound in the late r980. Compared with the more traditional temples in the vicinity, the Hare Krishna temple cannot claim particular importance, but the presence of foreign devotees has a certain attraction,

267 Vaudeville I976; Entwistle I987.

${ }^{268}$ www.iskconvrindavan.com (6.I0.2020). The temple name in Latin script is used in all languages that are offered on the website. 
particularly their dancing in the temple, which marks the place as one of the attractions of Vrndāvan for the pilgrims, much to the chagrin of the leadership of the more traditional orders. The relationship between different sacred places is also a relationship between different school-traditions and the temples they are related to. The status quo provides the basic terms of reference; that is why it is difficult for new formations like the Hare Krishna to intrude into the territory, even though they are economically strong and provide foreign devotees, who contribute to the attraction of the place. The Govardhan hill, however, is basically puștimārg territory. The famous Giridhar Nāgar in the puștimārg temple was initially installed in the I 520 s. Non-pusțimārgīs stay away from the temple-compound and very often from the mount itself. Instead, the circumambulation is a common way of pilgrimage, affirming the sacred status of the mount.

The discovery of places of Kṛṇa's "play" in Braj goes hand in hand with the production of narrations of the places and their relation to Kṛșna, the so-called sthalalīlās (local plays). Besides, lyric hymns on certain holy places (sthalapurānās, sthalamahātmyas) were constantly produced and - continuously important even today - descriptions of the attractions in the forest around Vrndāvan that the pilgrim might come across while circumambulating Vụndāvan (vanparikramā). Popular pamphlets with these hymns in Braj and Sanskrit are still on sale at many places at the places visited by pilgrims. Vṛndāvan is a growing town of about 65.000 inhabitants according to the 201 I census. Unfortunately, there is not much left of the mystical groves, where Kṛșna is said to have met his Gopīs overnight, that still existed in earlier centuries.

The fame of the Braj region has much to do with the missionary activities of Krishnaism and popular hymns. Particularly important are the hymns composed by a group of poets called Așțachāp, eight poets that are believed to belong to the puștimārg school, the undisputedly most famous of them being Sūrdās (I 478 ? - I 583 ?). ${ }^{269}$ As in the case of almost all devotional poets in a period of South Asian history, often called Early Modernity in more recent research, the historical figure of the poet is difficult to grasp beyond

269 Other members of the Aștchāp were Paramānanddās, Nanddās, Kṛ̣ṇadās, Govindswāmī, Kumbhandās, Chitaswāmī, and Caturbhujdās. 
the traditional narratives in hagiographical literature starting with Nābhādās' Bhaktamāl. ${ }^{270}$ Whether Sūrdās actually belonged to the pustimārg or not, it is clear that he had a close relationship to the Giridhar Nāgar temple in Govardhan. His poetry, however, was adopted in Kṛ̣na devotionalism beyond all limits and shaped the meaning of bhakti to quite some extent all over North India. The performance of these hymns in public space and in private was important for spreading the sense of sacredness of Braj, shaping a religious climate in which the attraction of the pilgrimage to the sacred region of Kṛṣna's pastimes played an important role.

\section{Traditional and modern criticism of pilgrimage}

In the canonical "History of Hindi literature" (Hindī sāhitya $k \bar{a}$ itihās, I942), Rāmcandra Śkla defined the period between I 375 Vikrama Samvat and I700 Vikrama Samvat (= I3 I7/I3 I 8I642/I $643 \mathrm{CE}$ ) as bhaktikāl, the period of devotional literature. This term is based on the theological content of some of the literature composed during this epoch; much of devotional literature that is still performed today is related to composers of bhaktikāl, but the extant corpus does not go back to manuscripts dating to the lifetime of the ascribed composers themselves. The modern Sürsāgar for example, a $20^{\text {th }}$ century edition of the corpus ascribed to Sūrdās by the Nāgarī Pracāriṇi Sabhā, contains about 5000 hymns. The tradition is cumulative, and numerous hymns that form part of the tradition have been composed in Sūrdās' style, but not by the historical composer.

What I would like to point out here is the importance of the binary of sagun and nirgun that Rāmcandra Śukla insists upon. Sagun bhakti is a devotion to a personal God, who is present in his statues, at holy places, and appears in history through a diversity of manifestations, particularly through his avatārs. Nirgun bhakti is supposed to focus on God's formless and universal appearance, and particularly in one's self. Nirgun bhakti is therefore critical of temple-service, bathing-rituals, social and religious hierarchies, and pilgrimage as such. The two forms of bhakti often go together in one way or another. Even poems under the name of Sūrdās

270 Compare Callewaert \& Snell i 994. 
may contain a eulogy of God as being identical with one's self. Śukla's effort was to give both forms of bhakti a clear-cut identity, while including them in a conclusive history of Hindi literature and Hinduism at the same time.

One of the most prominent devotional poets of the nirgun bhakti tradition is Ravidās ( $\mathrm{I} 5^{\text {th }}-\mathrm{I} 6^{\text {th }}$ century), a contemporary of Caitanya and Vallabhācārya. As in the case of Sūrdās, it is hardly possible to decide on the original corpus of Ravidās; much of the poetry that is ascribed to him is not composed by the historical poet-saint. One poem ascribed to Ravidās goes like this:

Where should I go?

You are everywhere. ${ }^{27 I}$

And the poem continues:

Why do you hold back your love, Keśav?

Remove my misfortune!

Ravidās says, I have become completely absent -

My mind fled, where should I go?

You are everywhere, Lord Govinda,

I am immersed within You alone.

In other words: the suffering from Krșna's absence is detached from any geographical space. The poem transforms the focus on Krṣna into a more monistic, panentheist interpretation of God's reality within the world. The hymn can illustrate the transformation of Krishnaism into some form of iconoclastic monism, which does not leave any room for sacredness of a geographical space. The hagiographical sources clearly report how this conceptualization of Krishnaism is related to the protest against the social hierarchy along caste lines. ${ }^{272}$ Perhaps the most famous saying of the tanner (camār) Ravidās is: man cangā to kațhorì mem gangā, "If the hart is pure, the Gangā can be found in a small vessel (filled with water)". In other word, purification is not bound to the access to prestigious bathing-places that are reserved for caste Hindus, particularly at Banaras and other famous places of pilgrimage along the river Gangā.

\footnotetext{
${ }^{271}$ Ravidās 38 in Callewaert \& Friedlander I992:I 27.

272 Hawley 2005:64.
} 
While the historical Kabīr, like Ravidās, was based in Banaras, perhaps the most prestigious places of pilgrimage along the Gangā, many poems in the Kabīr tradition explicitly declare the pilgrimage to Kāśî (Banaras) as well as the pilgrimage to Mekka as being meaningless. Similarly, mandir (temple) and masjid (mosque) have no meaning. Instead, God dwells in the human self and nowhere else:

There is nothing but water in the holy pools.

I know, I have been swimming in them.

All the gods, sculpted of wood or ivory can't say a word.

I know, I have been crying out to them.

The Sacred Books of the East are nothing but words.

I looked through their covers one day sideways.

What Kabīr talks of is only what he has lived through.

If you have not lived through something, it is not true. ${ }^{273}$

\section{From performance to transformation}

Another case of religious criticism of pilgrimage is to be found in the Sikh tradition, another product of South Asia's impressive transreligious spirituality of the Early Modern epoch. According to the traditional biography (Janamsākhì), Guru Nānak (I 469I 538 ), the historical founder of the Sikh religion, used to travel from one holy place to another during a long period of his life. $\mathrm{He}$ was particularly interested in visiting traditional places of pilgrimage - Muslim and Hindu. The story of his visit to Mekka and Medina are well known in the Sikh community until today. Though being non-Muslim, he turned towards Muslims with his message that the real pilgrimage to Mekka is not a physical journey, but a spiritual.

Janamsākh̄ 5 reports Nānak's spectacular fourth travel towards the West, to Mekka and Medina: He started to wear shoes made from leather and even leather-pants. He put a garland of bones around his neck and painted a red point on his forehead. As a child he used to wear blue clothes and now once again he put on blue clothes when he went to Mekka. He met a Hajjī (pilgrim to

273 Bly 2004:44. 
Mekka) and put up a joint overnight-stay. The Hajjī asked him: “My Darvīś (holy man), you don't have a wooden beggar's bowl, no leather-bag, no marijuana-pipe - nothing! Are you Hindu or Muslim?" Nānak answered:

The Fear of You, o Lord God, is my marijuana;

my consciousness is the pouch which holds it.

I have become an intoxicated hermit.

My hands are my begging bowl;

I am so hungry for the Blessed Vision of Your Darshan.

I beg at Your Door, day after day.

I long for the Blessed Vision of Your Darshan.

I am a beggar at Your Door - please bless me with Your charity. ${ }^{274}$

Darśan - in bhakti-terminology the visible appearance, for example of the Lord in the temple in form of his statue or of sacred places - is a centrepiece of Hindu devotionalism. Nānak transforms the traditional meaning of darśan into something that no longer relates to a fixed location. Darśan is a form of spiritual presence in front of the non-worldly divine. Nānak is a radical critique of the institution of pilgrimage. At the same time, certain holy places of the Sikhs developed into places of pilgrimage in the young Sikh community, starting during Guru Nānak's lifetime.

Nānak's relation to pilgrimage as an institution was paradoxical. He used to join pilgrimage-parties disguised as a pilgrim in order to preach about how useless the belief in the religious reward for religious journeying was. One of these journeys, mentioned in the Janamsākhī, was a visit at the Kumbh Mela in Allahabad. Nānak's spiritual friend and pupil Mardānā, a Muslim musician, accompanied him. They used to sit in the camp of the pilgrims and attract people to them by singing and holding sermons. Some monastic orders $(a k h \bar{a} r \bar{a})$ that had their camps close by considered killing Nānak, since he distracted pilgrims from meeting the monks and explained to them how useless it was to go on pilgrimage. One day Nānak followed one of the abbots (mahants) of an akhārāa to the Gangā, where the mahant would take his holy dip in the water; the following dialogue is reported:

${ }^{274}$ Guru Granth Sahib 721: www.srigurugranth.org/O721.html (24.1.2019) 
In a soft, gentle but clear voice he asked the mahant: 'Why did you bathe in the river?' 'Why did I bathe in the river?' the mahant repeated Nanak's words incredulously. 'You know well enough why we all bathed in the river. It was to wash away our sins.' 'What did you wash with your bath?' 'My body', the mahant replied, not yet getting the drift of Nanak's subtle questioning. 'Did your body commit your sins?'275

Nānak's point is that ritual purification with water is useless, since the person is responsible for his $\sin (p \bar{a} p)$, not his body. Purification is an inner process that involves the mind.

The Janamsākhis are full of this kind of narratives, in which Nānak does not teach directly, but demonstrates the absurdity of certain religious acts and beliefs by questioning the believers - the "maieutic" method of Socrates. In the end, many of the listeners to Nānak's questioning become aware of the wrongs of their doings or beliefs and, in the case of the abbots at the Kumbh Mela, Nānak ends up turning against his earlier conviction on the usefulness of pilgrimage and ritual purification by the Gangā’s water.

\section{Conclusion}

Reform Hinduism of the $19^{\text {th }}$ and $20^{\text {th }}$ centuries overwhelmingly followed the arguments against physical pilgrimage and either radically turned against it or believed in the metaphorical form of pilgrimage as spiritual transformation. The revival of vedānta tried to distinguish itself from the ascription of the divine to images, temples, ritual oblation, and places of pilgrimage. Besides, colonial vedānta often could see nothing but the superstition of pilgrims and the exploitation-strategies of greedy traders of religion in the notorious Paṇ̂ās, the priests at places of pilgrimage. If they had a positive attitude to the vocabulary of pilgrimage, it would be as metaphors for spiritual transformation.

This aversion to the localization of sacredness and the whole idea of spiritual transformation is present even in Mahatma Gandhi's critical statements on Zionism. The true Zion, he writes, is spiritual and not located in the outer world.

275 Dhillon 201 5: I $6 f$. 
Zionism in its spiritual sense is a lofty aspiration. By spiritual sense I mean they should want to realize the Jerusalem that is within. Zionism meaning re-occupation of Palestine has no attraction to me. ... The real Zionism of which I have given you my meaning is the thing to strive for, long for and die for. Zion lies in one's heart. It is the abode of God. The real Jerusalem is the spiritual Jerusalem. Thus he can realize this Zionism in any part of the world. ${ }^{276}$

Even Hermann Kallenbach, Gandhi's German-Jewish friend and supporter from his early activist days in South Africa, could not win over Gandhi's support for the Zionist movement, when he was sent by the World Zionist Organisation to India. Not even the open and massive antisemitism in Nazi Germany made Gandhi warm up for the idea of a Jewish state in Palestine; he insisted on a spiritualized conception of Zion. Gandhi used a trope that goes back to nirgun bhakti, in which the pilgrimage is a description of an inner travel, rather than a physical, and a form of spiritual transformation. Kabir says in one of his most famous couplets:

Musk is in the navel; the hare looks out for it all over the forest (without finding it).

In this way, God is to be found in everyone; the world doesn't see him. ${ }^{277}$

The sagun bhakti, however, continually supported the idea of localization of the sacred and of spiritual rewards through pilgrimage. In historical practice, sagun and nirgun somehow went hand in hand. The distinctive identities of the two types of bhakti, which Sukla tries to establish, are somewhat artificial. They do not mark exclusive alternatives, but two ends of a spectrum with authors and traditions floating freely between the two. Beyond that, the two types of bhakti inspire each other mutually and craft their identity in constant interaction with each other. As for many poetical traditions, looking into the detail of the theological

${ }^{276}$ Interview in The Jewish Chronicle, London, October 2, I93 I. Chapter 5 in Lev 2012 looks in more depth into the complex relationship of Gandhi to the idea of Zionism and Judaism. Thanks to Shimon Lev for this reference.

277 kastūrī kuṇdal basai mrigā ḍhūṃ̣hai ban māhìn / aise ghat ghaṭ mem rām hai duniyā dekhai nāhīm // (Kabīr I957:76) 
content, sagun and nirgun hardly form excluding alternatives, but rather mark the poles within the open range of devotional options.

It can be difficult to decide in detail whether a certain poem is more towards one pole of meaning or the other, sagun or nirgun. One of the efforts which negotiates between personalism and monism is the doctrine of the divine as being acintya bhedabheda, unthinkable separate and non-separate (from the individual self) at the same time. This theological argument is taken up by ISKCON-founder Prabhupad in the paradoxical formula (in English) "Supreme Personality of Godhead", which is the subtitle of his book about Kṛșna ${ }^{278}$, a formula that can only be understood in the context of the Indian tradition of reasoning on the nature of the divine and its manifestations, on the non-personal divine and the divine as person. The theological discourse on pilgrimage in Hindu tradition as a whole is embedded into the context of this discourse. The question is: How and where exactly does God manifest himself?

\section{References}

Ali, Daud. 2000. "From Nayika to Bhakta: A Genealogy of Female Subjectivity in Early Medieval India". In: Leslie, J. \& McGee, M. (eds.), Invented Identities: The Interplay of Gender, Religion, and Politics in India, Delhi: Oxford University Press.

Bakker, H. T. (ed.). I990. The History of Sacred Places in India as Reflected in Traditional Literature. Leiden: Brill.

Berreman, Gerald D. I963. Hindus of the Himalayas. Berkeley: University of California Press.

Bharati, Agehananda. I963. "Pilgrimage in the Indian tradition." In: History of Religion 3, I35-I67.

Bhardwaj, Surinder Mohan. 1973. Hindu Places of Pilgrimage in India: A Study in Cultural Geography. Berkeley: University of California Press.

I985. "Religion and circulation: Hindu pilgrimage". In: Prothero, R. M. \& Chapman, M. (eds.), Circulation in Third World Countries. London: Routledge, 24I-26I.

${ }^{278}$ www.krsnabook.com (I9.I.20I9) 
Bly, Robert. 2004. Kabir: Ecstatic Poems. Boston: Beacon Press.

Bremer, Thomas S. 2005. “Tourism and religion”. In: Encyclopedia of Religion (ed. Jones, $2^{\text {nd }}$ ed.) I3, Detroit, MI: Macmillan Reference USA, 9260-9264.

Callewaert, Winand M. \& Friedlander, Peter G. I992. The life and works of Raidās. New Delhi: Manohar.

Callewaert, Winand M. \& Snell, Rupert (ed.). I994. According to Tradition: Hagiographical Writing in India. Wiesbaden: Otto Harrassowitz.

Datar, Balwant N. I96I. Himalayan Pilgrimage. Delhi: Publication Division, Government of India.

Dhillon, Harish. 20I 5 . Janamsakhis: Ageless stories, Timeless Values. New Delhi: Hay House.

Eck, Diana. I98 I. "India's Tirthas: 'Crossing' in Sacred Geography”. In: History of Religions 21, 323-344.

Entwistle, Alan W. 1987. Braj: Centre of Krishna Pilgrimage. Groningen: Egbert Forsten.

Feldhaus, Anne. 2003. Connected Places: Religion, Pilgrimage, and Geographical Imagination in India. New York: Palgrave Macmillan.

Glasenapp, Helmuth von. 1928. Heilige Stätten Indiens. München: Georg Müller Verlag.

Hawley, John Stratton. 2005. Three Bhakti Voices: Mirabai, Surdas, and Kabir in Their Times and Ours. New Delhi: Oxford University Press.

Jacobsen, Knut A. 2009. "Tìrtha and tìrthayātrā: salvific space and pilgrimage". In: Brill's Encyclopedia of Hinduism (ed. Jacobsen), Leiden: Brill, 38 I-4 IO.

Kabīr: Vaudeville, Ch. I957. Kabir Granthavali (Doha). Avec introduction, traduction et notes. Pondichéry: Institut Français d'Indologie (Publications de l'Institut Français d'Indologie I 2.

Lev, Shimon. 2012. Soulmates: The Story of Mahatma Gandhi and Hermann Kallenbach. Delhi: Orient BlackSwan.

Lochtefeld, James. 20I0. God's Gateway: Identity and Meaning in a Hindu Pilgrimage Place. New Delhi: Oxford University Press. 
Mehrotra, Rahul (ed.). 201 5. Kumbh Mela: Studying the Ephemeral Megacity. Ostfildern: Hatje Cantz.

Mīrābāī: Alston, A. J. 1980. The Devotional Poems of Mirabai: Translated. New Delhi: Motilal Banarsidass.

Saha, Shandip. Creating a Community of Grace: A History of the Pusti Marga in Northern and Western India. www.columbia.edu /cgi-bin/cul/resolve?AQP0595 (I7.I.20I9)

Singh, Rana P.B. 2006. "Pilgrimage in Hinduism: Historical Context and Modern Perspectives". In: Timothy, Dallen J. \& Olsen, Daniel H. (eds.), Tourism, Religion, and Spiritual Journeys. London: Routledge, 220-236.

Stausberg, Michael. 20I0. Religion und moderner Tourismus. Berlin: Verlag der Weltreligionen.

Śukla, Rāmcandra. I942. Hind̄̄ sāhitya kā itihās. Vārāṇasī: Nāgarī Pracārin̄ī Sabhā. [Many reprints].

Vaudeville, Charlotte. I976. “Braj, Lost and Found”. In: Indo-Iranian Journal I 8, I95-2I3. Press. 